\title{
Zinc: A Necessary Ion for Mammalian Sperm Fertilization Competency
}

\author{
Karl Kerns ${ }^{1}$, Michal Zigo ${ }^{1}$ and Peter Sutovsky ${ }^{1,2, *(D)}$ \\ 1 Division of Animal Sciences, University of Missouri, Columbia, MO 65211-5300, USA; \\ kkerns@mail.missouri.edu (K.K.); zigom@missouri.edu (M.Z.) \\ 2 Department of Obstetrics, Gynecology and Women's Health, University of Missouri, Columbia, \\ MO 65211-5300, USA \\ * Correspondence: Sutovskyp@missouri.edu; Tel.: +1-573-882-3329
}

Received: 15 November 2018; Accepted: 14 December 2018; Published: 18 December 2018

\begin{abstract}
The importance of zinc for male fertility only emerged recently, being propelled in part by consumer interest in nutritional supplements containing ionic trace minerals. Here, we review the properties, biological roles and cellular mechanisms that are relevant to zinc function in the male reproductive system, survey available peer-reviewed data on nutritional zinc supplementation for fertility improvement in livestock animals and infertility therapy in men, and discuss the recently discovered signaling pathways involving zinc in sperm maturation and fertilization. Emphasis is on the zinc-interacting sperm proteome and its involvement in the regulation of sperm structure and function, from spermatogenesis and epididymal sperm maturation to sperm interactions with the female reproductive tract, capacitation, fertilization, and embryo development. Merits of dietary zinc supplementation and zinc inclusion into semen processing media are considered with livestock artificial insemination (AI) and human assisted reproductive therapy (ART) in mind. Collectively, the currently available data underline the importance of zinc ions for male fertility, which could be harnessed to improve human reproductive health and reproductive efficiency in agriculturally important livestock species. Further research will advance the field of sperm and fertilization biology, provide new research tools, and ultimately optimize semen processing procedures for human infertility therapy and livestock AI.
\end{abstract}

Keywords: fertilization; sperm; capacitation; zinc; proteasome; fertility

\section{Introduction-Encyclopedism of Biological Zinc}

Zinc $(\mathrm{Zn})$ is one of the most highly abundant elements on earth, an essential micronutrient to all things living, typically occurring as a divalent cation metal with moderate reactivity and reducing properties. Essential biological roles of zinc include signaling, enzymatic activities, regulation of normal growth and sexual maturation, digestion, homeostasis of central nervous system, and mitochondrial oxidative stress [1,2]. Conversely, zinc imbalance or altered zinc-signaling accompanies pathologies including but not limited to Alzheimer's disease [3-5], blindness, cancer, digestive ailments, growth retardation, and inflammation [6]. While ancient Etruscans and Romans may have already recognized medicinal properties of zinc salts [7], its biological importance was only fully realized in the 19th century, and it entered the mainstream human medicine hundred years later, when the first studied were conducted on dwarfism, human zinc deficiency, and general importance of zinc as a growth factor [8].

Cells of all organisms, ranging from E. coli to mammals, tightly regulate free zinc ion $\left(\mathrm{Zn}^{2+}\right)$ distribution, even though its toxicity is relatively low $[9,10]$. In humans, nearly $90 \%$ of $\mathrm{Zn}^{2+}$ is found in the muscle and bone [11]. Other organs containing significant concentrations of $\mathrm{Zn}^{2+}$ are the prostate, 
liver, gastrointestinal tract, kidney, skin, lung, brain, heart, and pancreas [12-14]. Homeostasis of $\mathrm{Zn}^{2+}$ is important for survival and fitness; thus, when $\mathrm{Zn}^{2+}$ is consumed in excess, it is important for the body to handle its surplus [15]. Upon ingestion and absorption through the small intestine, the redistribution of $\mathrm{Zn}^{2+}$ occurs via the serum, where $\mathrm{Zn}^{2+}$ is bound predominantly to albumin (major binding protein for up to $60 \%$ of $\mathrm{Zn}^{2+}$ ); the remaining $\mathrm{Zn}^{2+}$ is bound predominantly to 12 other proteins, including $\alpha_{2}$-macroglobulin, transferrin, ceruloplasmin, IgG, $\operatorname{IgA}, \operatorname{IgM}$, complement C4, haptoglobin, and prealbumin $[16,17]$. Serum $\mathrm{Zn}^{2+}$ accounts for only $~ 0.1 \%$ of bodily $\mathrm{Zn}^{2+}$ [18]. Further, there is no known specialized $\mathrm{Zn}^{2+}$ storage system in the body, and therefore only the daily intake of $\mathrm{Zn}^{2+}$ will ensure steady availability [17].

On the cellular level, $30-40 \%$ of $\mathrm{Zn}^{2+}$ localizes in the nucleus, while $50 \%$ is stored in the cytoplasm and the rest is associated with membranes [19]. There are two families of proteins that are responsible for the movement of $\mathrm{Zn}^{2+}$ through biological membranes, thus exercising sustained homeostatic control. These include zinc-importer (ZIP; Zrt-, Irt-like) family proteins that transport $\mathrm{Zn}^{2+}$ into the cytosol and the zinc transporter ( $\mathrm{ZnT}$ ) family proteins transporting $\mathrm{Zn}^{2+}$ out of the cytosol [20]. Completion of human genome sequencing identified 14 members of ZIP (designated ZIP1-14) and 10 members ZnT (designated ZnT1-10) [20] families. Few studies have inspected major tissues for the expression patterns of ZnTs in humans [21], and the expression of ZIPs during spermatogenesis is only known in mice [22]. Once $\mathrm{Zn}^{2+}$ enters a cell by ZnTs and ZIPs, it becomes sequestered within the endoplasmic reticulum, mitochondria, and Golgi, or other cell type-specific membrane bound vesicular structures, also called zincomsomes [23,24]. Cytosolic $\mathrm{Zn}^{2+}$ complexing with cytosolic proteins maintains the concentration of free cytosolic $\mathrm{Zn}^{2+}$ within range between picomoles and nanomoles, depending on the cell type $[9,25-27]$. Up to $20 \%$ of cytosolic $\mathrm{Zn}^{2+}$ is bound by the apoprotein thionein, to form metallothionein (MT). MTs are small ubiquitous proteins $(6-7 \mathrm{kDa})$ that are rich in cysteine that can complex transition metal ions [28,29]. One molecule of MT can bind up to seven $\mathrm{Zn}^{2+}$, buff excess $\mathrm{Zn}^{2+}$, and supply such cation under $\mathrm{Zn}^{2+}$ deficiency states [30,31].

Limited information exists on the regulation of $\mathrm{Zn}^{2+}$ homeostasis in reproductive system. In female gametes, $\mathrm{Zn}^{2+}$ plays a gatekeeping role in regulating meiotic resumption [32-34]. A novel phenomenon of $\mathrm{Zn}^{2+}$ release from the mammalian oocyte at fertilization was recently reported [33,35]; inspiring some of the work on male gametes that will be discussed later. The importance of $\mathrm{Zn}^{2+}$ for male fertility only emerged recently, propelled in part by consumer interest in nutritional supplements containing ionic trace minerals. Here, we review properties, biological roles, and cellular mechanisms that are relevant to zinc function in the male reproductive system, survey available peer-reviewed data on nutritional zinc supplementation for fertility improvement in livestock animals and infertility therapy in men, and discuss recently discovered signaling pathways involving zinc in sperm maturation and fertilization.

\section{Zinc-Interacting Sperm Proteins}

In eel, zinc is necessary for the sustenance of germ cells and spermatogenesis progression, with $N, N, N^{\prime}, N^{\prime}$-tetrakis(2-pyridinylmethyl)-1,2-ethanediamine (TPEN)-induced Zn deficiency causing germ cell apoptosis [36]. Zinc transporters have been examined in rat, specifically MT I \& II in spermatocytes [37] as well as tesmin, a testis-specific metallothionein-like protein [38]. Further, ZnT-7 in mouse testis may supply spermatogenesis-required zinc [39]. $\mathrm{Zn}^{2+}$ transporter ZIP9 serves as a membrane-associated receptor interacting with G-protein Gn $\alpha 11$ to mediate the non-classical testosterone signaling cascade in murine spermatogenic GC-2 cells [40]. Further, the spontaneous $\mathrm{Ca}^{2+}$ oscillations that were observed in spermatogenic cells seem to be modulated by $\mathrm{Zn}^{2+}$ [41]. Zinc ions begin to colonize spermatogenic cells during the final stages of spermatid differentiation when they are incorporated in the nucleus [42] and nascent outer dense fibers (ODF) [43,44]. Additional $\mathrm{Zn}^{2+}$ is incorporated into the nucleus at ejaculation [45]. Nuclear $\mathrm{Zn}^{2+}$ associates with protamines and forms zinc bridges, most likely through imidazole groups of histidine and thiols of cysteine [46], as proposed by Bjorndahl and Kvist, to stabilize the sperm chromatin structure $[47,48]$. These authors 
showed that a rapid sperm chromatin decondensation can be induced by $\mathrm{Zn}^{2+}$ chelation with $2,2^{\prime}, 2^{\prime \prime}, 2^{\prime \prime \prime}$-(Ethane-1,2-diyldinitrilo) tetraacetic acid (EDTA), causing the disruption of the protamine zinc bridges [49-51]. In the sperm flagellum, $\mathrm{Zn}^{2+}$ is bound to sulfhydryl groups of ODF protein cysteine groups, to protect the nascent flagellum from premature oxidation [52]. During epididymal transit, $\mathrm{Zn}^{2+}$ is selectively removed from the flagellum by a $160 \mathrm{kDa}$ protein, enabling the oxidation of sulfhydryl groups and stiffening the ODF to support progressive motility [52]. High concentrations of $\mathrm{Zn}^{2+}$ have been found in the acrosome [53] and proteolytic conversion of proacrosin to acrosin is inhibited by $\mathrm{Zn}^{2+}[54,55]$, as it probably involves $\mathrm{Zn}$-dependent metalloproteinases. Zinc ions also associate with sperm membranes, where they interact with lipoproteins and membrane-bound metalloproteins in which they react with sulfhydryl groups of cysteine and therefore fulfill a membrane stabilizing function $[56,57]$. The active removal of $\mathrm{Zn}^{2+}$ is therefore a prerequisite for the completion of sperm capacitation [53], a complex structural and molecular remodeling event that endows spermatozoa within the female reproductive tract with the ability to fertilize. High concentrations of $\mathrm{Zn}^{2+}(100 \mu \mathrm{M})$ reduce sperm motility in a reversible manner [58]. Initiation of motility following ejaculation [59] and the increased motility of the capacitation-induced sperm hyperactivation are both dependent upon intracellular alkalinization [60].

Additional $\mathrm{Zn}^{2+}$ becomes incorporated into spermatozoa during ejaculation [21,45] where it is believed to have protective function in terms of sperm chromatin decondensation [47,48], sperm motility and metabolic inhibition [58,61], membrane stabilization [56], and antioxidant activity $[62,63]$. As $\mathrm{Zn}^{2+}$ becomes incorporated into spermatozoa upon mixing with seminal fluid, there are also seminal fluid $\mathrm{Zn}$-interacting proteins competitively binding free $\mathrm{Zn}^{2+}$. In humans, a bulk of seminal fluid $\mathrm{Zn}^{2+}$ is bound to high and low molecular weight ligands derived from prostatic and vesicular secretions [64-67]. Among them, semenogelins participate in the formation of coagulum, to prevent the retrograde flow of semen deposited in the female tract. Prostasomes, small, exosome-like lipoprotein vesicles are the main zinc-binding partners in human seminal fluid [68,69]. Zinc-binding proteins have also been found in seminal fluid of boar [70] and dog [71,72], and are designated as ZnBP1-6.

\section{Zinc-Containing Sperm Proteins}

Zinc-containing proteins, commonly known as metalloproteins, are capable of binding one or more $\mathrm{Zn}^{2+}$, usually as a requirement for their biological activity. Human genome sequencing and combined proteomic approaches independently identified 1684 proteins in the human proteome as zinc-containing proteins [73]. Metalloproteins can be further divided into three groups, i.e., (i) metalloenzymes, (ii) metallothioneins, and (iii) gene regulatory proteins [19,74]. Metallothioneins have been discussed in the previous section. Gene regulatory proteins are nucleoproteins that are directly involved with the replication and transcription of DNA. Such DNA binding proteins can be further categorized into three structurally distinct groups, containing: (i) zinc fingers, (ii) zinc clusters, or (iii) zinc twists [75]. Spermatozoa may have limited use for gene regulatory proteins since they are transcriptionally silent; however, these proteins, as, for instance, protamine P2 (discussed earlier) are used heavily for DNA condensation, packaging, and transcriptional suppression [76]. The majority of this section will therefore be dedicated to zinc-containing metalloenzymes, which play a vital role in sperm function.

More than 300 enzymes have been identified that require $\mathrm{Zn}^{2+}$ for their function [19], representing more than 50 different enzyme types. $\mathrm{Zn}^{2+}$ is the only metal that is encountered in all six classes of enzymes, (i.e., oxidoreductases, transferases, hydrolases, lyases, isomerases, and ligases). This can be attributed to two properties of $\mathrm{Zn}^{2+}$ : (i) relatively low toxicity when compared to other transition metals [77] and (ii) stable association and coordination flexibility with macromolecules [78]. $\mathrm{Zn}^{2+}$ fulfills three functions in the Zn-enzymes: (i) catalytic, (ii) co-active (co-catalytic), and (iii) structural [79]. Catalytic $\mathrm{Zn}^{2+}$ takes part directly in enzyme catalysis. Co-active $\mathrm{Zn}^{2+}$ enhances or diminishes catalytic function in conjunction with catalytic $\mathrm{Zn}^{2+}$, but it is not indispensable for catalytic function [79]. Structural $\mathrm{Zn}^{2+}$ is required for stabilization of the quaternary structure of oligomeric enzymes. 
Matrix metalloproteinases (MMPs) belong to a family of zinc-dependent endopeptidases, which are involved in the degradation of extracellular matrix proteins. Since the first discovery of MMPs in the early 1960s, MMPs have grown in number and at least 28 species have been identified to this date; for subtype categorization, distribution, and substrate specificities, see review by Cui et al. [80]. Structurally, a typical MMP contains a propeptide, a catalytic metalloproteinase domain, a linker peptide (hinge region), and a hemopexin domain [80]. The catalytic domain contains two $\mathrm{Zn}^{2+}$ (catalytic and structural) and up to three calcium ions $\left(\mathrm{Ca}^{2+}\right)$, which stabilize the structure. The cysteine rich region in propeptide chelates the catalytic $\mathrm{Zn}^{2+}$, keeping MMPs in an inactive zymogen form [81]. MMP2 and MMP9, also referred to as Gelatinase-A and Gelatinase-B, were described in human seminal fluid $[82,83]$ and canine epididymal fluid and seminal fluid $[84,85]$. Furthermore, MMP2 was found to be localized in acrosomal and tail region of normal morphological ejaculated human and canine spermatozoa, while MMP9 was localized in the tail region $[85,86]$. High levels of MMP2 are associated with high (70\%) motility and significantly elevated levels of MMP9 are observed in semen samples with low sperm count [85]. Ferrer at al. [87] demonstrated that MMP2 together with acrosin were confined to the inner acrosomal membrane of epididymal bull sperm and thus introducing the possibility of their cooperation in enzymatic digestion of the oocyte zona pellucida (ZP) during penetration. The regulation of said MMPs by zinc ion fluxes associated with sperm capacitation is currently under investigation. Kratz et al., [88] demonstrated that the levels of seminal MMP2 and MMP9 are correlated with oxidative stress in men, making this a potential diagnostic tool for semen quality/male infertility. Finally, Atabakhsh et al. [89] noticed a positive correlation between seminal fluid MMP2 activity and sperm count, as well as fertilization and embryo quality in couples undergoing assisted reproductive therapy (ART) by intracytoplasmic sperm injection (ICSI), offering a potential predictor of ICSI outcome.

Superoxide dismutases (SOD) are metalloenzymes that are responsible for dismutating the superoxide anion $\left(\mathrm{O}_{2}{ }^{-}\right)$, to hydrogen peroxide $\left(\mathrm{H}_{2} \mathrm{O}_{2}\right)$, and oxygen $\left(\mathrm{O}_{2}\right)$ [90]. Three isoforms have been reported in mammals: (i) the cytosolic dimeric $\mathrm{Cu} / \mathrm{Zn}-\mathrm{SOD}$ (SOD1), (ii) the mitochondrial matrix Mn-SOD (SOD2), and (iii) the secretory tetrameric extracellular SOD (EC-SOD/SOD3) [91]. It was shown earlier that both seminal fluid and spermatozoa contain SOD activity [92-99], of which 75\% was attributed to SOD1, which is also the main SOD isoform in spermatozoa SOD. The SOD activity in spermatozoa is several-fold higher than SOD activity levels that were previously measured in more than 50 different human somatic cell types [98]. O'Flaherty et al. [94] suggested an important role of superoxide anion in sperm hyperactivation and capacitation; therefore, an adequate balance between superoxide radical generation and dismutation is vital for proper function of spermatozoa, as implicated by Sikka [100].

Another significant group of $\mathrm{Zn}^{2+}$ containing proteins of spermatozoa are sorbitol dehydrogenases that convert sorbitol to fructose, and endow spermatozoa with and have been correlated to motility [101]. Lactate dehydrogenase isoenzyme (LDH-X, $\left.\mathrm{LDH}-\mathrm{C}_{4}\right)$ also has been reported to have relationship with sperm motility [102-104]. It was shown at least in mice that the inhibition of LDH-C 4 blocked sperm capacitation [105]. We previously reported the presence of a ring finger ubiquitin ligase homologous to UBR7 in round spermatids and spermatozoa [106], and implicated this zinc finger containing enzyme in spermiogenesis and possibly in the proteolytic degradation of the ZP at fertilization [107]. Angiotensin converting enzyme (ACE), yet another important $\mathrm{Zn}^{2+}$ containing protein, has been reported in testis, epididymis, and spermatozoa of stallion, boar, and man [108-114]. Several roles in reproduction have been proposed for ACE, including spermatogenesis [115], sperm capacitation [116,117], and sperm-ZP binding [118]. Alkaline phosphatase (ALP), a homodimeric enzyme containing two $\mathrm{Zn}^{2+}$ and one $\mathrm{Mg}^{2+}$ is present in mammalian seminal fluid [119,120] and spermatozoa [121]. The precise role of ALP in reproduction remains to be discovered, though it may serve as a decapacitating factor [122]. Additional $\mathrm{Zn}^{2+}$ containing proteins that are found in the spermatozoa include fructose-bisphosphate aldolases [123], of which class-II possesses $\mathrm{Zn}^{2+}$ [124], and alcohol dehydrogenase present in human testis and spermatozoa [125,126]. The ADAM (A Disintegrin and Metalloproteinase) protein family 
plays a role in multiple events leading up to fertilization, including gamete migration and sperm reservoir interactions, sperm-oocyte ZP binding, and sperm-oocyte plasma membrane adhesion and fusion (see review [127]). Noteworthy, proteins in this family possess metalloproteinase domains with $\mathrm{Zn}^{2+}$ [128]. The metalloproteinase domain, however, is cleaved during epididymal transit and only the disintegrin domain remains in mature spermatozoon [127]. Altogether, it is likely that the zinc-interacting proteome plays varied and often essential roles in the regulation of sperm homeostasis and fertilizing ability. Rather than a complete list of zinc-containing proteins, we focused on proteins that are well characterized. We are aware that there are many zinc-containing proteins to be characterized in spermatozoa.

\section{Zinc as a Regulator of Sperm Capacitation and Fertilization}

Zinc ions play a vital role in sperm capacitation, regulating key events that are responsible for fertilization competency (summarized in Figure 1a). As much as the $\mathrm{Ca}^{2+}$ influx was understood as key for capacitation, today it is understood that the $\mathrm{Zn}^{2+}$ efflux is the gatekeeper to this important $\mathrm{Ca}^{2+}$ influx [129-132]. In the following discussion of sperm capacitation, it is important to note the contrasting definitions of sperm capacitation (physiological vs. biochemical) [133] and we will discuss it strictly from the earlier in its original definition (the acquisition of the capacity to fertilize [134]). Prior to the discovery of the sperm capacitation state-reflecting Zn signatures in higher order mammals (boar, bull, and human) [135], there was a noticeable paucity of pivotal discoveries in sperm capacitation translatable from rodent models to humans [136]. Much of this was criticized as a lack of in vivo or minimal inclusion of an in vitro female component in sperm capacitation studies; however, a critical review of literature suggests that this could be due to subtle but vivid differences in the study models and/or experimental design. This includes species differences in attaining intracellular alkalinization [137], thus regulating $\mathrm{Ca}^{2+}$ entry (solely the $\mathrm{Na}^{+}$-dependent $\mathrm{Cl}^{-} / \mathrm{HCO}_{3}{ }^{-}$ exchanger [138] and possibly the sperm-specific $\mathrm{Na}^{+} / \mathrm{H}^{+}$exchanger sNHE [139] in murine; hydrogen voltage-gated channel, Hv1 expressed by HVCN1 in humans [140]), as well as a result of using epididymal spermatozoa (as opposed to ejaculated). Both of these factors have a notable impact on the Zn signature and result in studies that do not mimic the physiology of ejaculated human semen.

There is a moderate negative correlation between flagellar $\mathrm{Zn}^{2+}$ content, and sperm global and progressive motility in humans [141]. Chelation of sperm $\mathrm{Zn}^{2+}$ by $(2 R, 3 S)-2,3-\mathrm{Bis}$ (sulfanyl)butanedioic acid (DMSA), 2,3-dimercaptopropane-1-sulfonate (DMPS), or DL-penicillamine leads to increased average straight line velocity and progressive sperm motility while decreasing the percentage of nonlinear motile spermatozoa [142]. Though discovered before the importance of Hv1 in sperm motility activation and capacitation surfaced, previous authors believed this $\mathrm{Zn}^{2+}$ removal to be solely associated with the stiffening of the ODF. Voltage-gated proton channel, Hv1 localizes to the sperm flagellum and it is responsible for sperm cytoplasmic alkalinization through transmembrane proton extrusion [61]. Hv1 is asymmetrically positioned, likely providing differing alkalized microenvironments and gradients in relationship to the symmetrically positioned CatSper channels, thereby being responsible for asymmetrical flagellar bending during hyperactivation [143].

The sperm $\mathrm{Zn}$ signature is a collective term for four distinct $\mathrm{Zn}^{2+}$ localization patterns that are indicative of the sperm capacitation state [135]. These zinc ion fluxes are associated with key events in the acquisition of fertilization competency, indicating non-capacitated state, hyperactivation, acrosomal modifications, and acrosomal exocytosis (summarized in Figure 1b). These distinct signatures minimally distinguish the sequential sperm capacitation subpopulations, or to the extent that $\mathrm{Zn}^{2+}$ establishes these sequential subpopulations, and thereby is the previously unknown regulatory time clock of sperm capacitation. The decrease in $\mathrm{Zn}^{2+}$ concentration from the ejaculation/deposition site to the site of fertilization could remove sperm $\mathrm{Zn}^{2+}$ simply via concentration gradient differences and the filtering out of seminal fluid, thereby promoting sperm capacitation. Further, it is well understood that the ubiquitin-dependent protease holoenzyme, the $26 \mathrm{~S}$ proteasome regulates sperm capacitation (review [144]), as well as the $\mathrm{Zn}^{2+}$ flux in boar spermatozoa [135], and participates 
in sperm acrosomal exocytosis induced by binding to the egg coat in sea urchin [145], bull [146], and human [147] spermatozoa. Besides acrosomal exocytosis, the sperm-borne 26S proteasome has been implicated in egg coat penetration (ascidian, sea urchin [145], and boar [107]). The relationship between $26 \mathrm{~S}$ proteasome activity and $\mathrm{Zn}^{2+}$ is unclear, though the proteasomal regulatory subunit PSMD14/Rpn11 contains a metalloprotease-like $\mathrm{Zn}^{2+}$ site [148]. Additionally, $\mathrm{Zn}^{2+}$ has been implicated in regulating proteasome-dependent proteolysis in HeLa cells [149]. Contrarily to the high seminal fluid $\mathrm{Zn}^{2+}$ concentrations ( $2 \mathrm{mM}$ ) inhibiting Hv1, lower concentrations (20 and $\left.50 \mu \mathrm{M}\right)$ have been implicated in promoting acrosomal exocytosis in sea urchin [150] and bovine [151] spermatozoa during in vitro capacitation. It is believed that $\mathrm{Zn}^{2+}$ interacts with $\mathrm{Zn}$-sensing receptor (ZnR) GPR39 of the G-protein-coupled receptor (GPCR) family that is found in the sperm acrosome. Such interaction stimulates acrosomal exocytosis through epidermal growth factor receptor (EGFR) transactivation and the phosphorylation of phosphoinositide 3-kinase (PI3K) causing acrosomal $\mathrm{Ca}^{2+}$ mobilization [151]. This implicates a multifaceted role of $\mathrm{Zn}^{2+}$ in sperm capacitation and therefore more research will be needed to fully comprehend these contrasting pathways (inhibiting vs. inducing acrosomal exocytosis).

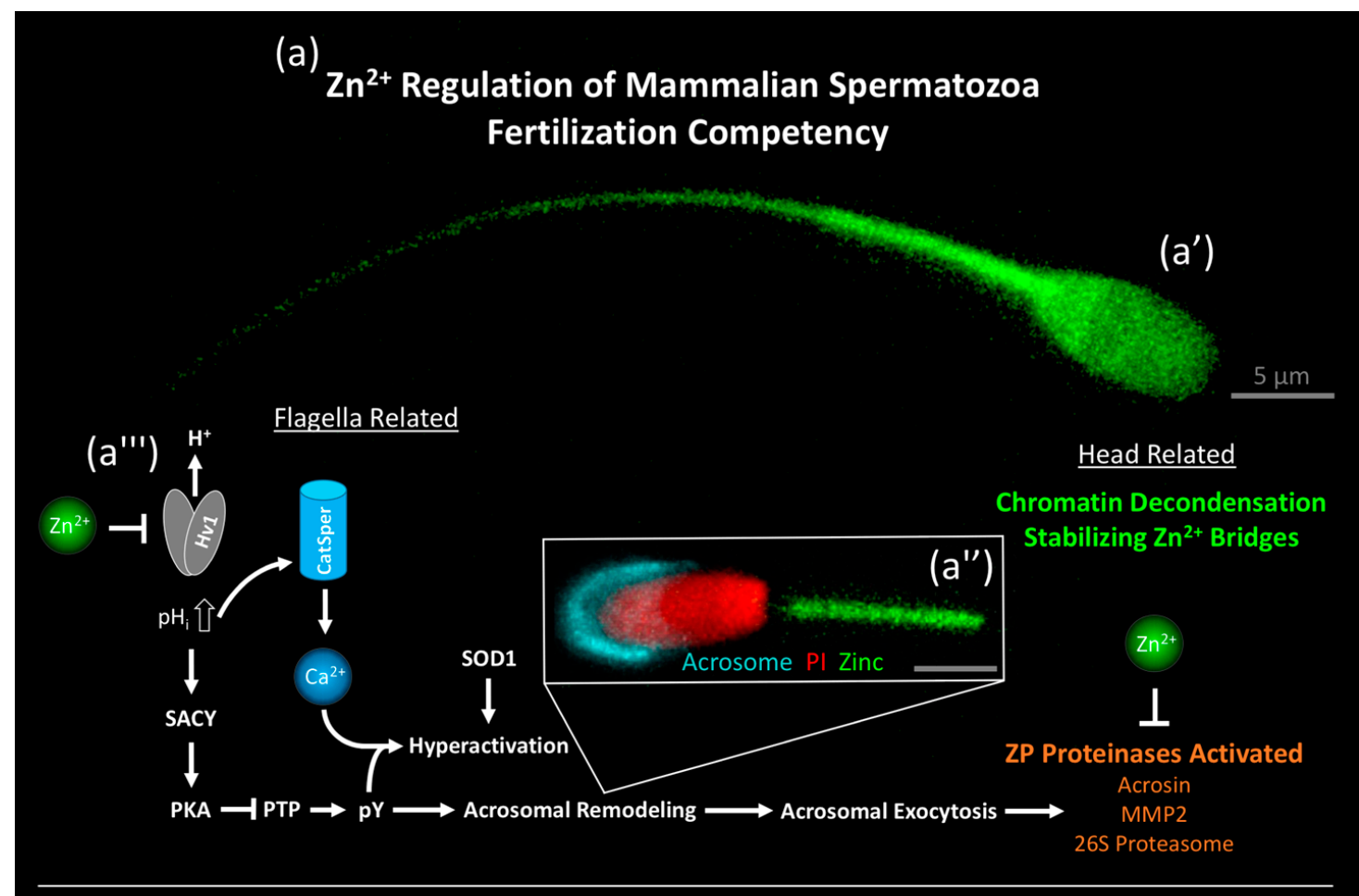

(b) Capacitation-indicating State of the Zinc Signatures

Signature 1

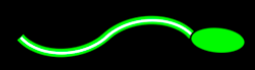

Noncapacitated

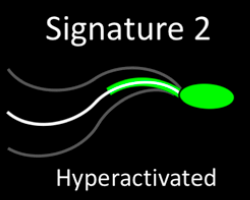

Susceptible to Chemoattractant

$\left(P_{4}\right)$

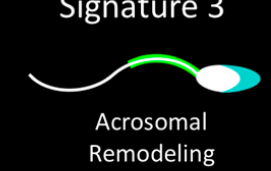

Signature 4

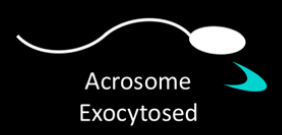

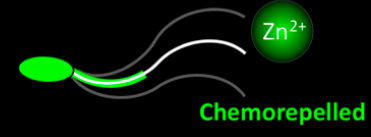

Figure 1. Summary of Zinc $(\mathrm{Zn})$ signatures and free zinc ion $\left(\mathrm{Zn}^{2+}\right)$ regulation of the fertilization competency of mammalian spermatozoa. (a) Super-resolution images of the non-capacitated boar sperm Zn signature 1 ( $\left.\mathbf{a}^{\prime}\right)$ and acrosome-remodeled sperm Zn signature 3 (a") acquired by the Leica TCP SP8 stimulated emission depletion (STED) microscope (free zinc ions in green, outer acrosomal 
membrane in cyan, remodeled sperm head plasma membrane in red; scale bars in gray: $5 \mu \mathrm{m}$ ). (a"') High $\mathrm{Zn}^{2+}$ concentration $(2 \mathrm{mM})$ negatively regulates proton channel Hv1, responsible for the rise of intracellular $\mathrm{pH}$, facilitating: (1) $\mathrm{Ca}^{2+}$ entry via CatSper and (2) protein tyrosine phosphorylation (pY), triggered by activation of soluble sperm adenylyl cyclase (SACY), increasing intracellular cAMP, activating protein kinase A (PKA) and phosphorylating protein tyrosine phosphatases (PTP) to an inactive state. For general capacitation pathway, review see Kerns et al., [144]). Following acrosome remodeling and exocytosis, zona pellucida (ZP) proteinases (acrosin, MMP2, and the $26 \mathrm{~S}$ proteasome) implicated in endowing the spermatozoon with the ability to penetrate the ZP are activated. $\mathrm{Zn}^{2+}$, abundantly present in the fertilizing sperm triggered oocyte zinc shield, negatively regulates proteinase activities of spermatozoa bound to the zona or present in the perivitelline space, de-capacitating spermatozoa and serving as a newly proposed anti-polyspermy defense mechanism. (b) Capacitation-indicating state of the zinc signatures. Signature 1 spermatozoa are in a non-capacitated state. Signature 2 spermatozoa display hyperactivated motility. Only capacitating spermatozoa susceptible to progesterone $\left(\mathrm{P}_{4}\right)$ chemoattraction exhibit chemorepulsion by $\mathrm{Zn}^{2+}$. Signature 3 spermatozoa exhibit acrosome remodeling while acrosomal exocytosis reportedly occurs in signature 4 .

Successful embryo development in mammals depends upon efficient anti-polyspermy defense, preventing the entry of more than one spermatozoon in the oocyte cytoplasm at fertilization, and thus alleviating an embryo-lethal polyploidy. While membrane depolarization and cortical granule exocytosis are regarded as the main barriers to polyspermy, a sperm-induced $\mathrm{Zn}^{2+}$ release from the oocyte cortex, nicknamed the $\mathrm{Zn}^{2+}$ spark, has recently been discovered in mammals [33,35]. Besides the oocyte $\mathrm{Zn}^{2+}$ spark [33], there is also a physiochemical $\mathrm{ZP}$ hardening and a $300 \% \mathrm{Zn}^{2+}$ increase in the ZP matrix observed when the fertilized oocyte zona becomes refractory to sperm binding in the mouse [35]. Such a proposed new anti-polyspermy defense mechanism is plausible, although the exact mechanism was not known until recently. We now know that $\mathrm{Zn}^{2+}$ is chemorepulsive, possibly overriding the chemoattraction of oocyte-secreted progesterone in capacitated human, mouse, and rabbit spermatozoa [152]. In light of the sperm Zn signature, a polyspermy defense mechanism of newly fertilized oocytes, termed the zinc shield [135], could in fact de-capacitate spermatozoa already bound to the zona or present in the perivitelline space at the time of fertilization. It is likely such hijacking sperm Zn-signaling and de-capacitation complements the blockage of fertilization through traditional anti-polyspermy mechanisms. $\mathrm{Zn}^{2+}$ has been shown to inhibit fertilization when added to bovine in vitro fertilization (IVF) media [153]. In further support of this mechanism, $\mathrm{Zn}^{2+}$ regulates the activity of the proposed sperm-borne ZP lysins, the proteinases [87] implicated in ZP penetration, including acrosin [54,55], 26S proteasome [135,144], and MMP2 (brain) [154], therefore playing a regulatory role in sperm-ZP penetration. Additionally, inhibitors of zinc-dependent metalloproteases hinder sperm passage through the cumulus oophorus during porcine IVF [155].

\section{Effect of Zinc Supplementation on Male Fertility}

Reduced seminal fluid $\mathrm{Zn}^{2+}$ has been reported in cases of male infertility that are associated with accidental Chernobyl radiation in Ukraine [156], signifying a possible relationship between $\mathrm{Zn}^{2+}$ and male fertility. Indeed, seminal fluid $\mathrm{Zn}^{2+}$ concentration is positively correlated with sperm count and normal sperm morphology [157]. Consequently, $\mathrm{Zn}^{2+}$ supplementation improves sexual dysfunction in rats [158] and uremic men [159], which is likely due to the ability of $\mathrm{Zn}^{2+}$ to increase serum testosterone levels [160]. The negative effect of fatiguing bicycle exercise on thyroid hormone and testosterone levels in sedentary males is likewise prevented with $\mathrm{Zn}^{2+}$ supplementation [161]. Oral $\mathrm{Zn}^{2+}$ supplementation results in increased sperm counts in ram [162] and humans (combined with inclusion of folate; review) [163]. Zinc supplementation also restores superoxide scavenging antioxidant capacity in asthenospermic men [164]. Dietary $\mathrm{Zn}^{2+}$ intake and action on intraprostatic $\mathrm{Zn}^{2+}$ levels remain unknown; however, if such supplementation increases prostatic levels, it could perceivably increase the percent of non-capacitated signature 1 spermatozoa at the time of ejaculation. Such would be beneficial for inhibiting Hv1, warding off premature sperm capacitation. Goat dietary 
$\mathrm{Zn}^{2+}$ supplementation increases sperm plasma membrane and acrosome integrity, and percent of viable spermatozoa, also increasing seminal fluid SOD, catalase, and glutathione peroxidase activities [63]. Additionally, $\mathrm{Cu}^{2+}$ and $\mathrm{Zn}^{2+}$ dietary co-supplementation to bucks of the Osmanabadi goat breed allowed for them to reach puberty 28-35 days earlier [165]. While $\mathrm{Zn}^{2+}$ supplementation has a positive influence on multiple male reproductive measures and can serve as male infertility therapy under certain circumstances, one study suggests that supplementation over $100 \mathrm{mg} /$ day is associated with a 2.29 relative risk of advanced prostate cancer [166]. The exact mechanism is unclear, as $\mathrm{Zn}^{2+}$ is not generally considered a carcinogen [167]; yet, increased risk is not surprising as zinc becomes cytotoxic at such concentrations and warrants dosage caution.

Few studies have assessed the addition of $\mathrm{Zn}^{2+}$ in media/semen extenders in agriculturally important livestock species propagated by artificial insemination (AI). A highly desirable property of such media is to reduce reactive oxygen species (ROS) that effect sperm function by the oxidation of lipids, proteins, and DNA (review [168]). Notably, $\mathrm{Zn}^{2+}$ supplementation would serve as an antioxidant by scavenging excessive superoxide anions [169], though $\mathrm{Zn}^{2+}$ homoeostasis is important, and too much $\mathrm{Zn}^{2+}$ can act as a prooxidant and cause mitochondrial oxidative stress (review [2]). Some studies have investigated $\mathrm{Zn}^{2+}$ supplementation, however they did so with the inclusion of D-aspartate and coenzyme Q10, without distinguishing which compound positively reduced lipid peroxidation and DNA fragmentation [170] and improved embryo development [171]. Spermatozoa have the capacity for $\mathrm{Zn}^{2+}$ loading [135], to the extent of restoring their pre-capacitation $\mathrm{Zn}$ signature, and it seems reasonable that such would reduce premature, pathological sperm capacitation.

\section{Spermatotoxicity and Reprotoxicity of High Zinc Contamination and Zinc Deficiency}

At high soil levels, $\mathrm{Zn}^{2+}$ is reprotoxic to the terrestrial worm Enchutraeus crypticus [172]. Few studies exist that observe $\mathrm{Zn}^{2+}$ reprotoxicity [173]. $\mathrm{ZnCl}_{2}$ dietary supplementation to both male and female rats at $30 \mathrm{mg} / \mathrm{kg} /$ day but not 15 or $7.5 \mathrm{mg} / \mathrm{kg} /$ day showed significant reduction in fertility, offspring viability, and body weight of F1 pups; however, it had no effect on litter size (male reprotoxicity alone was not observed) [174]. Nanosized ZnO toxicity induces sea urchin sperm DNA damage, but it does not reduce fertility [175]. A moderate negative correlation $(r=-0.426)$ has been found between total flagellar $\mathrm{Zn}^{2+}$ content and the percentage of morphologically normal spermatozoa in men [141]. Morphologically abnormal spermatozoa actually contained high amounts of $\mathrm{Zn}^{2+}$ (as reported by fluorescent $\mathrm{Zn}$-probe) [135]. Whether such is caused by $\mathrm{Zn}^{2+}$ toxicity or simply a product of defective spermatozoa failing to regulate their ion fluxes is unknown. Dietary $\mathrm{Zn}^{2+}$ deficiency studies in rat have shown reduced relative weight of the testes, epididymides, and seminal vesicles (organ by percentage of body weight) and reduced prostate weight (by organ weight alone). In the same study, the length of the flagellum was reduced on average by $24 \%$ in $\mathrm{Zn}^{2+}$ deficient rats, accompanied by a substantial increase in morphologically abnormal spermatozoa (especially abnormal heads, predominantly headless). Some of these defects could be due to abnormal testicular function from modulated fatty acid composition, interrupting essential fatty acid metabolism, where $\omega-6$ polyunsaturated fatty acids were highly enriched [176]. $\mathrm{Zn}^{2+}$ deficiency is known to trigger autophagy in yeast [177], and elevated autophagy rate during spermatogenesis could decrease sperm count during $\mathrm{Zn}^{2+}$ deficiency. In the absence of fertilization, sperm capacitation is a terminal event leading down a rapid path of apoptosis [178], possibly from the overproduction of ROS [179] in an environment with reduced $\mathrm{Zn}^{2+}$. No studies have been performed to observe whether micromolar levels of $\mathrm{Zn}^{2+}$ under capacitation-inducing conditions can prolong sperm lifespan during a fertilization competent state (as opposed to millimolar levels which inhibit sperm $\mathrm{Zn}^{2+}$ flux [135]). If such could be achieved, fertilization would be possible with fewer spermatozoa and especially useful for artificial insemination in livestock as well as human intrauterine insemination (IUI) in place of costly IVF treatments of couples with an oligospermic male partner. 


\section{Conclusions and Perspectives}

Through a variety of pathways, $\mathrm{Zn}^{2+}$ plays a gatekeeping role in male gametes just as it does in those of the female. Prostatic seminal fluid with the highest concentration of $\mathrm{Zn}^{2+}$ found in any bodily fluids plays a crucial role in fending off premature sperm capacitation and it provides antioxidant activity, while lower concentrations of $\mathrm{Zn}^{2+}$ may be a prerequisite for successful acrosomal exocytosis. A list of reviewed $\mathrm{Zn}$-containing and interacting proteins that are involved from spermatogenesis through the final preparatory steps of fertilization is summarized in Table 1. To fully understand the biological role of $\mathrm{Zn}^{2+}$ in male fertility, further research needs to be pursued, especially to fully disclose the Zn-interacting sperm proteome and its place in various cellular pathways controlling male reproductive function. Additionally, dietary and semen media $\mathrm{Zn}^{2+}$ supplementation has been found to be beneficial for male fertility. Collectively, the currently available data already hint at the importance of zinc ions for male fertility, which could be harnessed to improve the reproductive performance of livestock and increase the success rate of human assisted reproductive therapy. Further research will advance the field of sperm and fertilization biology, provide new research tools, and ultimately optimize the semen processing procedures for human infertility therapy and livestock artificial insemination.

Table 1. General summary of testicular/sperm Zn-containing and interacting proteins reviewed, in order of discussion.

\begin{tabular}{|c|c|c|c|}
\hline Protein & Localization $^{1}$ & Function $^{2}$ & Reference \\
\hline Metallothionein I \& II & Spermatocytes (rat) & Zinc ion binding & [37] \\
\hline Tesmin & Spermatocytes (rat) & Developmental protein & [37] \\
\hline Protamine-2 & Sperm nucleus (man) & Developmental protein, DNA-binding & {$[42,47,48]$} \\
\hline Acrosin & Acrosome (man, bull) & Hydrolase, protease, serine protease & {$[54,55]$} \\
\hline Semenoglins & Prostatic and vesicular fluids (man) & - & [64-67] \\
\hline Matrix metalloproteinase- 2 & $\begin{array}{l}\text { Seminal fluid, inner acrosomal } \\
\text { membrane, flagellum (man, bull) }\end{array}$ & Hydrolase, metalloprotease, protease & [87] \\
\hline Matrix metalloproteinase- 9 & Seminal fluid and flagellum (man, bull) & Hydrolase, metalloprotease, protease & [87] \\
\hline Superoxide dismutase $1,2,3$ & Mitochondria and seminal fluids (man) & Antioxidant, oxidoreductase & [91-99] \\
\hline L-lactate dehydrogenase & Seminal fluids (man) & Oxidoreductase & [102-104] \\
\hline Putative class-II fructose-bisphosphate aldolase & Spermatozoa (bull) & Lyase & [123] \\
\hline Alcohol dehydrogenase class-3 & Testis, spermatozoa (man) & Oxidoreductase & {$[125,126]$} \\
\hline ADAMs & Spermatozoa & Integrin binding, metalloendopeptidase & Review [127] \\
\hline Voltage-gated hydrogen channel 1 & Flagellum (man) & Ion channel & [140] \\
\hline G-protein coupled receptor & Acrosome (bull) & G-protein coupled receptor activity & [151] \\
\hline 26S proteasome non-ATPase regulatory subunit 14 & Inner acrosomal membrane & Hydrolase, metalloprotease, protease & [180] \\
\hline
\end{tabular}

${ }^{1}$ Including species reported. ${ }^{2}$ Known or predicted function.

Author Contributions: All authors contributed to investigation, original draft preparation, review and editing; visualization, K.K.; supervision, P.S.; project administration, P.S.; funding acquisition, P.S. and K.K.

Funding: This review was funded by National Institute of Food and Agriculture (NIFA), U.S. Department of Agriculture (USDA) grant number 2015-67015-23231 (P.S.), USDA NIFA Graduate Fellowship award number 2017-67011-26023 (K.K.), grant number 5 R01 HD084353-02 from National Institutes of Health (NIH) National Institute of Child and Human Development (P.S.), and seed funding from the Food for the 21st Century Program of the University of Missouri (P.S.).

Acknowledgments: We thank Alexander Jurkevich and Robert Baker of the University of Missouri Molecular Cytology Core in assistance of $\mathrm{Zn}$ signature super-resolution imaging. We also thank Ms. Katherine Craighead for clerical support.

Conflicts of Interest: The authors declare no conflict of interest. The funders had no role in this review; in the collection, analyses, or interpretation; in the writing of the manuscript, or in the decision to publish the results. 


\section{Abbreviations}

MDPI Multidisciplinary Digital Publishing Institute

AI Artificial insemination

Zn Zinc

$\mathrm{Zn}^{2+} \quad$ Zinc ion

ZIP Zrt- and Irt-like protein

ZnT Zinc transporter

MT Metallothionein

TPEN $N, N, N^{\prime}, N^{\prime}$-tetrakis(2-pyridinylmethyl)-1,2-ethanediamine

ODF Outer dense fibers

EDTA 2,2',2",2 $22^{\prime \prime \prime}$-(Ethane-1,2-diyldinitrilo)tetraacetic acid

ZnBP Zinc-binding proteins

MMP Matrix metalloproteinase

$\mathrm{Ca}^{2+} \quad$ Calcium ion

ZP Zona pellucida

ICSI Intracytoplasmic sperm injection

SOD Superoxide dismutase

LDH Lactate dehydrogenase

ACE Angiotensin converting enzyme

ALP Alkaline phosphatase

ADAM A disintegrin and metalloproteinase

Hv1 Hydrogen voltage-gated channel 1

DMSA $\quad(2 R, 3 S)-2,3-$ Bis(sulfanyl)butanedioic acid

DMPS 2,3-dimercaptopropane-1-sulfonate

ZnR Zn-sensing receptor

GPCR G-protein-coupled receptor

EGFR Epidermal growth factor receptor

PI3K Phosphoinositide 3-kinase

IVF In vitro fertilization

pY Protein tyrosine phosphorylation

SACY Soluble sperm adenylyl cyclase

PKA Protein kinase A

PTP Protein tyrosine phosphatase

ROS Reactive oxygen species

IUI Intrauterine insemination

\section{References}

1. Levaot, N.; Hershfinkel, M. How cellular $\mathrm{Zn}^{2+}$ signaling drives physiological functions. Cell Calcium 2018, 75, 53-63. [CrossRef] [PubMed]

2. Lee, S.R. Critical Role of Zinc as Either an Antioxidant or a Prooxidant in Cellular Systems. Oxid. Med. Cell. Longev. 2018, 2018, 9156285. [CrossRef] [PubMed]

3. Lovell, M.A. A potential role for alterations of zinc and zinc transport proteins in the progression of Alzheimer's disease. J. Alzheimer's Dis. 2009, 16, 471-483. [CrossRef] [PubMed]

4. Szewczyk, B. Zinc homeostasis and neurodegenerative disorders. Front. Aging Neurosc. 2013, 5, 33. [CrossRef] [PubMed]

5. Prakash, A.; Bharti, K.; Majeed, A.B. Zinc: Indications in brain disorders. Fundament. Clin. Pharmacol. 2015, 29, 131-149. [CrossRef] [PubMed]

6. Prasad, A.S. Zinc: Role in immunity, oxidative stress and chronic inflammation. Curr. Opin. Clin. Nutr. Metab. Care 2009, 12, 646-652. [CrossRef] [PubMed]

7. Giachi, G.; Pallecchi, P.; Romualdi, A.; Ribechini, E.; Lucejko, J.J.; Colombini, M.P.; Mariotti Lippi, M. Ingredients of a 2,000-y-old medicine revealed by chemical, mineralogical, and botanical investigations. Proc. Natl. Acad. Sci. USA 2013, 110, 1193-1196. [CrossRef] [PubMed] 
8. Prasad, A.S. Discovery of human zinc deficiency: Its impact on human health and disease. Adv. Nutr. 2013, 4, 176-190. [CrossRef] [PubMed]

9. Outten, C.E.; O'Halloran, T.V. Femtomolar sensitivity of metalloregulatory proteins controlling zinc homeostasis. Science 2001, 292, 2488-2492. [CrossRef] [PubMed]

10. Beyersmann, D.; Haase, H. Functions of zinc in signaling, proliferation and differentiation of mammalian cells. Biometals 2001, 14, 331-341. [CrossRef] [PubMed]

11. Wastney, M.E.; Aamodt, R.L.; Rumble, W.F.; Henkin, R.I. Kinetic analysis of zinc metabolism and its regulation in normal humans. Am. J. Physiol. 1986, 251 Pt 2, R398-R408. [CrossRef]

12. Bentley, P.J.; Grubb, B.R. Effects of a zinc-deficient diet on tissue zinc concentrations in rabbits. J. Anim. Sci. 1991, 69, 4876-4882. [CrossRef] [PubMed]

13. He, L.S.; Yan, X.S.; Wu, D.C. Age-dependent variation of zinc-65 metabolism in LACA mice. Int. J. Radiat. Biol. 1991, 60, 907-916. [PubMed]

14. Llobet, J.M.; Domingo, J.L.; Colomina, M.T.; Mayayo, E.; Corbella, J. Subchronic oral toxicity of zinc in rats. Bull. Environ. Contam. Toxicol. 1988, 41, 36-43. [CrossRef] [PubMed]

15. Jones, M.M.; Schoenheit, J.E.; Weaver, A.D. Pretreatment and heavy metal LD50 values. Toxicol. Appl. Pharmacol. 1979, 49, 41-44. [CrossRef]

16. Prasad, A.S.; Oberleas, D. Binding of zinc to amino acids and serum proteins in vitro. J. Lab. Clin. Med. 1970, 76, 416-425. [PubMed]

17. Scott, B.J.; Bradwell, A.R. Identification of the serum binding proteins for iron, zinc, cadmium, nickel, and calcium. Clin. Chem. 1983, 29, 629-633. [PubMed]

18. Rukgauer, M.; Klein, J.; Kruse-Jarres, J.D. Reference values for the trace elements copper, manganese, selenium, and zinc in the serum/plasma of children, adolescents, and adults. J. Trace Elem. Med. Biol. 1997, 11, 92-98. [CrossRef]

19. Vallee, B.L.; Falchuk, K.H. The biochemical basis of zinc physiology. Physiol. Rev. 1993, 73, 79-118. [CrossRef] [PubMed]

20. Lichten, L.A.; Cousins, R.J. Mammalian zinc transporters: Nutritional and physiologic regulation. Ann. Rev. Nutr. 2009, 29, 153-176. [CrossRef] [PubMed]

21. Foresta, C.; Garolla, A.; Cosci, I.; Menegazzo, M.; Ferigo, M.; Gandin, V.; De Toni, L. Role of zinc trafficking in male fertility: From germ to sperm. Hum. Reprod. 2014, 29, 1134-1145. [CrossRef] [PubMed]

22. Croxford, T.P.; McCormick, N.H.; Kelleher, S.L. Moderate zinc deficiency reduces testicular Zip6 and Zip10 abundance and impairs spermatogenesis in mice. J. Nutr. 2011, 141, 359-365. [CrossRef] [PubMed]

23. Zalewski, P.D.; Forbes, I.J.; Betts, W.H. Correlation of apoptosis with change in intracellular labile Zn(II) using zinquin [(2-methyl-8-p-toluenesulphonamido-6-quinolyloxy)acetic acid], a new specific fluorescent probe for Zn(II). Biochem. J. 1993, 296 Pt 2, 403-408. [CrossRef]

24. Wellenreuther, G.; Cianci, M.; Tucoulou, R.; Meyer-Klaucke, W.; Haase, H. The ligand environment of zinc stored in vesicles. Biochem. Biophys. Res. Commun. 2009, 380, 198-203. [CrossRef] [PubMed]

25. Qin, Y.; Dittmer, P.J.; Park, J.G.; Jansen, K.B.; Palmer, A.E. Measuring steady-state and dynamic endoplasmic reticulum and Golgi $\mathrm{Zn}^{2+}$ with genetically encoded sensors. Proc. Natl. Acad. Sci. USA 2011, 108, 7351-7356. [CrossRef] [PubMed]

26. Sensi, S.L.; Canzoniero, L.M.; Yu, S.P.; Ying, H.S.; Koh, J.Y.; Kerchner, G.A.; Choi, D.W. Measurement of intracellular free zinc in living cortical neurons: Routes of entry. J. Neurosci. 1997, 17, 9554-9564. [CrossRef] [PubMed]

27. Vinkenborg, J.L.; Nicolson, T.J.; Bellomo, E.A.; Koay, M.S.; Rutter, G.A.; Merkx, M. Genetically encoded FRET sensors to monitor intracellular $\mathrm{Zn}^{2+}$ homeostasis. Nat. Methods 2009, 6, 737-740. [CrossRef] [PubMed]

28. Tapiero, H.; Tew, K.D. Trace elements in human physiology and pathology: Zinc and metallothioneins. Biomed. Pharmacother. 2003, 57, 399-411. [CrossRef]

29. Coyle, P.; Philcox, J.C.; Carey, L.C.; Rofe, A.M. Metallothionein: The multipurpose protein. Cell. Mol. Life Sci. 2002, 59, 627-647. [CrossRef] [PubMed]

30. Blindauer, C.A.; Leszczyszyn, O.I. Metallothioneins: Unparalleled diversity in structures and functions for metal ion homeostasis and more. Nat. Prod. Rep. 2010, 27, 720-741. [CrossRef] [PubMed]

31. Maret, W.; Krezel, A. Cellular zinc and redox buffering capacity of metallothionein/thionein in health and disease. Mol. Med. 2007, 13, 371-375. [CrossRef] [PubMed] 
32. Zhao, M.H.; Kwon, J.W.; Liang, S.; Kim, S.H.; Li, Y.H.; Oh, J.S.; Kim, N.H.; Cui, X.S. Zinc regulates meiotic resumption in porcine oocytes via a protein kinase C-related pathway. PLoS ONE 2014, 9, e102097. [CrossRef] [PubMed]

33. Kim, A.M.; Bernhardt, M.L.; Kong, B.Y.; Ahn, R.W.; Vogt, S.; Woodruff, T.K.; O’Halloran, T.V. Zinc sparks are triggered by fertilization and facilitate cell cycle resumption in mammalian eggs. ACS Chem. Biol. 2011, 6, 716-723. [CrossRef] [PubMed]

34. Kim, A.M.; Vogt, S.; O'Halloran, T.V.; Woodruff, T.K. Zinc availability regulates exit from meiosis in maturing mammalian oocytes. Nat. Chem. Biol. 2010, 6, 674-681. [CrossRef] [PubMed]

35. Que, E.L.; Duncan, F.E.; Bayer, A.R.; Philips, S.J.; Roth, E.W.; Bleher, R.; Gleber, S.C.; Vogt, S.; Woodruff, T.K.; O'Halloran, T.V. Zinc sparks induce physiochemical changes in the egg zona pellucida that prevent polyspermy. Integr. Biol. 2017, 9, 135-144. [CrossRef] [PubMed]

36. Yamaguchi, S.; Miura, C.; Kikuchi, K.; Celino, F.T.; Agusa, T.; Tanabe, S.; Miura, T. Zinc is an essential trace element for spermatogenesis. Proc. Natl. Acad. Sci. USA 2009, 106, 10859-10864. [CrossRef] [PubMed]

37. Elgazar, V.; Razanov, V.; Stoltenberg, M.; Hershfinkel, M.; Huleihel, M.; Nitzan, Y.B.; Lunenfeld, E.; Sekler, I.; Silverman, W.F. Zinc-regulating proteins, ZnT-1, and metallothionein I/II are present in different cell populations in the mouse testis. J. Histochem. Cytochem. 2005, 53, 905-912. [CrossRef] [PubMed]

38. Sugihara, T.; Wadhwa, R.; Kaul, S.C.; Mitsui, Y. A novel testis-specific metallothionein-like protein, tesmin, is an early marker of male germ cell differentiation. Genomics 1999, 57, 130-136. [CrossRef] [PubMed]

39. Chi, Z.H.; Feng, W.Y.; Gao, H.L.; Zheng, W.; Huang, L.; Wang, Z.Y. ZNT7 and Zn ${ }^{2+}$ are present in different cell populations in the mouse testis. Histol. Histopathol. 2009, 24, 25-30. [PubMed]

40. Shihan, M.; Chan, K.H.; Konrad, L.; Scheiner-Bobis, G. Non-classical testosterone signaling in spermatogenic GC-2 cells is mediated through ZIP9 interacting with Gnalpha11. Cell. Signal. 2015, 27, 2077-2086. [CrossRef] [PubMed]

41. Lopez-Gonzalez, I.; Trevino, C.L.; Darszon, A. Regulation of Spermatogenic Cell T-Type Ca ${ }^{2+}$ Currents by $\mathrm{Zn}^{2+}$ : Implications in Male Reproductive Physiology. J. Cell. Physiol. 2016, 231, 659-667. [CrossRef] [PubMed]

42. Barney, G.H.; Orgebin-Crist, M.C.; Macapinalac, M.P. Genesis of esophageal parakeratosis and histologic changes in the testes of the zinc-deficient rat and their reversal by zinc repletion. J. Nutr. 1968, 95, 526-534. [CrossRef] [PubMed]

43. Baccetti, B.; Pallini, V.; Burrini, A.G. The accessory fibers of the sperm tail. II. Their role in binding zinc in mammals and cephalopods. J. Ultrastruct. Res. 1976, 54, 261-275. [CrossRef]

44. Bedford, J.M.; Calvin, H.I. Changes in -S-S- linked structures of the sperm tail during epididymal maturation, with comparative observations in sub-mammalian species. J. Exp. Zool. 1974, 187, 181-204. [CrossRef] [PubMed]

45. Bjorndahl, L.; Kjellberg, S.; Roomans, G.M.; Kvist, U. The human sperm nucleus takes up zinc at ejaculation. Int. J. Androl. 1986, 9, 77-80. [CrossRef] [PubMed]

46. Porath, J.; Carlsson, J.; Olsson, I.; Belfrage, G. Metal chelate affinity chromatography, a new approach to protein fractionation. Nature 1975, 258, 598-599. [CrossRef] [PubMed]

47. Bjorndahl, L.; Kvist, U. Human sperm chromatin stabilization: A proposed model including zinc bridges. Mol. Hum. Reprod. 2010, 16, 23-29. [CrossRef] [PubMed]

48. Bjorndahl, L.; Kvist, U. A model for the importance of zinc in the dynamics of human sperm chromatin stabilization after ejaculation in relation to sperm DNA vulnerability. Syst. Biol. Reprod. Med. 2011, 57, 86-92. [CrossRef] [PubMed]

49. Kvist, U. Importance of spermatozoal zinc as temporary inhibitor of sperm nuclear chromatin decondensation ability in man. Acta Physiol. Scand. 1980, 109, 79-84. [CrossRef] [PubMed]

50. Kvist, U. Sperm nuclear chromatin decondensation ability. An in vitro study on ejaculated human spermatozoa. Acta Physiol. Scand. Suppl. 1980, 486, 1-24. [PubMed]

51. Roomans, G.M.; Lundevall, E.; Bjorndahl, L.; Kvist, U. Removal of zinc from subcellular regions of human spermatozoa by EDTA treatment studied by X-ray microanalysis. Int. J. Androl. 1982, 5, 478-486. [CrossRef] [PubMed]

52. Henkel, R.; Baldauf, C.; Bittner, J.; Weidner, W.; Miska, W. Elimination of zinc from the flagella of spermatozoa during epididymal transit is important for motility. Reprod. Technol. 2001, 10, 6. 
53. Andrews, J.C.; Nolan, J.P.; Hammerstedt, R.H.; Bavister, B.D. Role of zinc during hamster sperm capacitation. Biol. Reprod. 1994, 51, 1238-1247. [CrossRef]

54. Steven, F.S.; Griffin, M.M.; Chantler, E.N. Inhibition of human and bovine sperm acrosin by divalent metal ions. Possible role of zinc as a regulator of acrosin activity. Int. J. Androl. 1982, 5, 401-412. [CrossRef] [PubMed]

55. Johnsen, O.; Eliasson, R.; Lofman, C.O. Inhibition of the gelatinolytic and esterolytic activity of human sperm acrosin by zinc. Acta Physiol. Scand. 1982, 114, 475-476. [CrossRef] [PubMed]

56. Bettger, W.J.; O'Dell, B.L. A critical physiological role of zinc in the structure and function of biomembranes. Life Sci. 1981, 28, 1425-1438. [CrossRef]

57. Mankad, M.; Sathawara, N.G.; Doshi, H.; Saiyed, H.N.; Kumar, S. Seminal plasma zinc concentration and alpha-glucosidase activity with respect to semen quality. Biol. Trace Elem. Res. 2006, 110, 97-106. [CrossRef]

58. Riffo, M.; Leiva, S.; Astudillo, J. Effect of zinc on human sperm motility and the acrosome reaction. Int. J. Androl. 1992, 15, 229-237. [CrossRef] [PubMed]

59. Acott, T.S.; Carr, D.W. Inhibition of bovine spermatozoa by caudal epididymal fluid: II. Interaction of $\mathrm{pH}$ and a quiescence factor. Biol. Reprod. 1984, 30, 926-935. [CrossRef]

60. Ho, H.C.; Granish, K.A.; Suarez, S.S. Hyperactivated motility of bull sperm is triggered at the axoneme by $\mathrm{Ca}^{2+}$ and not cAMP. Dev. Biol. 2002, 250, 208-217. [CrossRef] [PubMed]

61. Babcock, D.F.; Rufo, G.A., Jr.; Lardy, H.A. Potassium-dependent increases in cytosolic pH stimulate metabolism and motility of mammalian sperm. Proc. Natl. Acad. Sci. USA 1983, 80, 1327-1331. [CrossRef] [PubMed]

62. Bray, T.M.; Bettger, W.J. The physiological role of zinc as an antioxidant. Free Radic. Biol. Med. 1990, 8, 281-291. [CrossRef]

63. Narasimhaiah, M.; Arunachalam, A.; Sellappan, S.; Mayasula, V.K.; Guvvala, P.R.; Ghosh, S.K.; Chandra, V.; Ghosh, J.; Kumar, H. Organic zinc and copper supplementation on antioxidant protective mechanism and their correlation with sperm functional characteristics in goats. Reprod. Domest. Anim. 2018, 53, 644-654. [CrossRef] [PubMed]

64. Arver, S. Zinc and zinc ligands in human seminal plasma. I. Methodological aspects and normal findings. Int. J. Androl. 1980, 3, 629-642. [CrossRef] [PubMed]

65. Arver, S.; Eliasson, R. Zinc and zinc ligands in human seminal plasma. II. Contribution by ligands of different origin to the zinc binding properties of human seminal plasma. Acta Physiol. Scand. 1982, 115, 217-224. [CrossRef] [PubMed]

66. Arver, S. Zinc and zinc ligands in human seminal plasma. III. The principal low molecular weight zinc ligand in prostatic secretion and seminal plasma. Acta Physiol. Scand. 1982, 116, 67-73. [CrossRef] [PubMed]

67. Siciliano, L.; De Stefano, C.; Petroni, M.F.; Vivacqua, A.; Rago, V.; Carpino, A. Prostatic origin of a zinc binding high molecular weight protein complex in human seminal plasma. Mol. Hum. Reprod. 2000, 6, 215-218. [CrossRef] [PubMed]

68. Robert, M.; Gagnon, C. Semenogelin I: A coagulum forming, multifunctional seminal vesicle protein. Cell. Mol. Life Sci. 1999, 55, 944-960. [CrossRef] [PubMed]

69. Vivacqua, A.; Siciliano, L.; Sabato, M.; Palma, A.; Carpino, A. Prostasomes as zinc ligands in human seminal plasma. Int. J. Androl. 2004, 27, 27-31. [CrossRef] [PubMed]

70. Mogielnicka-Brzozowska, M.; Wysocki, P.; Strzezek, J.; Kordan, W. Zinc-binding proteins from boar seminal plasma-Isolation, biochemical characteristics and influence on spermatozoa stored at 4 degrees C. Acta Biochim. Pol. 2011, 58, 171-177. [PubMed]

71. Johnson, L.; Wikström, S.; Nylander, G. The Vehicle for Zinc in the Prostatic Secretion of Dogs. Scand. J. Urol. Nephrol. 1969, 3, 9-11. [CrossRef] [PubMed]

72. Mogielnicka-Brzozowska, M.; Strzezek, R.; Wasilewska, K.; Kordan, W. Prostasomes of canine seminal plasma-Zinc-binding ability and effects on motility characteristics and plasma membrane integrity of spermatozoa. Reprod. Domest. Anim. 2015, 50, 484-491. [CrossRef] [PubMed]

73. Andreini, C.; Banci, L.; Bertini, I.; Rosato, A. Counting the zinc-proteins encoded in the human genome. J. Proteome Res. 2006, 5, 196-201. [CrossRef] [PubMed]

74. Coleman, J.E. Zinc proteins: Enzymes, storage proteins, transcription factors, and replication proteins. Ann. Rev. Biochem. 1992, 61, 897-946. [CrossRef] [PubMed] 
75. Vallee, B.L.; Coleman, J.E.; Auld, D.S. Zinc fingers, zinc clusters, and zinc twists in DNA-binding protein domains. Proc. Natl. Acad. Sci. USA 1991, 88, 999-1003. [CrossRef] [PubMed]

76. Bianchi, F.; Rousseaux-Prevost, R.; Sautiere, P.; Rousseaux, J. P2 protamines from human sperm are zinc -finger proteins with one CYS2/HIS2 motif. Biochem. Biophys. Res. Commun. 1992, 182, 540-547. [CrossRef]

77. Seiler, H.G.; Sigel, H. Handbook on Toxicity of Inorganic Compounds; Marcel Dekker: New York, NY, USA, 1988.

78. Vallee, B.L.; Auld, D.S. Zinc coordination, function, and structure of zinc enzymes and other proteins. Biochemistry 1990, 29, 5647-5659. [CrossRef] [PubMed]

79. Vallee, B.L.; Auld, D.S. Active zinc binding sites of zinc metalloenzymes. In Matrix Metalloproteinases and Inhibitors; Birkedal-Hansen, H., Werb, Z., Welgus, H., Van Wart, H., Eds.; Fischer: Stuttgart, Germany, 1992; p. 5.

80. Cui, N.; Hu, M.; Khalil, R.A. Biochemical and Biological Attributes of Matrix Metalloproteinases. Prog. Mol. Biol. Transl. Sci. 2017, 147, 1-73. [PubMed]

81. Nagase, H.; Visse, R.; Murphy, G. Structure and function of matrix metalloproteinases and TIMPs. Cardiovasc. Res. 2006, 69, 562-573. [CrossRef] [PubMed]

82. Shimokawa Ki, K.; Katayama, M.; Matsuda, Y.; Takahashi, H.; Hara, I.; Sato, H.; Kaneko, S. Matrix metalloproteinase (MMP)-2 and MMP-9 activities in human seminal plasma. Mol. Hum. Reprod. 2002, 8, 32-36. [CrossRef] [PubMed]

83. Tentes, I.; Asimakopoulos, B.; Mourvati, E.; Diedrich, K.; Al-Hasani, S.; Nikolettos, N. Matrix metalloproteinase (MMP)-2 and MMP-9 in seminal plasma. J. Assist. Reprod. Genet. 2007, 24, 278-281. [CrossRef] [PubMed]

84. Saengsoi, W.; Shia, W.Y.; Shyu, C.L.; Wu, J.T.; Warinrak, C.; Lee, W.M.; Cheng, F.P. Detection of matrix metalloproteinase (MMP)-2 and MMP-9 in canine seminal plasma. Anim. Reprod. Sci. 2011, 127, 114-119. [CrossRef] [PubMed]

85. Warinrak, C.; Wu, J.T.; Hsu, W.L.; Liao, J.W.; Chang, S.C.; Cheng, F.P. Expression of matrix metalloproteinases (MMP-2, MMP-9) and their inhibitors (TIMP-1, TIMP-2) in canine testis, epididymis and semen. Reprod. Domest. Anim. 2015, 50, 48-57. [CrossRef] [PubMed]

86. Buchman-Shaked, O.; Kraiem, Z.; Gonen, Y.; Goldman, S. Presence of matrix metalloproteinases and tissue inhibitor of matrix metalloproteinase in human sperm. J. Androl. 2002, 23, 702-708. [PubMed]

87. Ferrer, M.; Rodriguez, H.; Zara, L.; Yu, Y.; Xu, W.; Oko, R. MMP2 and acrosin are major proteinases associated with the inner acrosomal membrane and may cooperate in sperm penetration of the zona pellucida during fertilization. Cell. Tissue Res. 2012, 349, 881-895. [CrossRef] [PubMed]

88. Kratz, E.M.; Kaluza, A.; Ferens-Sieczkowska, M.; Olejnik, B.; Fiutek, R.; Zimmer, M.; Piwowar, A. Gelatinases and their tissue inhibitors are associated with oxidative stress: A potential set of markers connected with male infertility. Reprod. Fertil. Dev. 2016, 28, 1029-1037. [CrossRef] [PubMed]

89. Atabakhsh, M.; Khodadadi, I.; Amiri, I.; Mahjub, H.; Tavilani, H. Activity of Matrix Metalloproteinase 2 and 9 in Follicular Fluid and Seminal Plasma and Its Relation to Embryo Quality and Fertilization Rate. J. Reprod. Infertil. 2018, 19, 140-145. [PubMed]

90. McCord, J.M.; Fridovich, I. Superoxide dismutase. An enzymic function for erythrocuprein (hemocuprein). J. Biol. Chem. 1969, 244, 6049-6055. [PubMed]

91. Marklund, S.L. Extracellular superoxide dismutase and other superoxide dismutase isoenzymes in tissues from nine mammalian species. Biochem. J. 1984, 222, 649-655. [CrossRef] [PubMed]

92. Alvarez, J.G.; Touchstone, J.C.; Blasco, L.; Storey, B.T. Spontaneous lipid peroxidation and production of hydrogen peroxide and superoxide in human spermatozoa. Superoxide dismutase as major enzyme protectant against oxygen toxicity. J. Androl. 1987, 8, 338-348. [CrossRef] [PubMed]

93. Beconi, M.T.; Francia, C.R.; Mora, N.G.; Affranchino, M.A. Effect of natural antioxidants on frozen bovine semen preservation. Theriogenology 1993, 40, 841-851. [CrossRef]

94. O'Flaherty, C.; Beconi, M.; Beorlegui, N. Effect of natural antioxidants, superoxide dismutase and hydrogen peroxide on capacitation of frozen-thawed bull spermatozoa. Andrologia 1997, 29, 269-275. [CrossRef] [PubMed]

95. Kowalowka, M.; Wysocki, P.; Fraser, L.; Strzezek, J. Extracellular superoxide dismutase of boar seminal plasma. Reprod. Domest. Anim. 2008, 43, 490-496. [CrossRef] [PubMed]

96. Strzezek, R.; Fraser, L. Characteristics of spermatozoa of whole ejaculate and sperm-rich fraction of dog semen following exposure to media varying in osmolality. Reprod. Biol. 2009, 9, 113-126. [CrossRef] 
97. Marti, E.; Mara, L.; Marti, J.I.; Muino-Blanco, T.; Cebrian-Perez, J.A. Seasonal variations in antioxidant enzyme activity in ram seminal plasma. Theriogenology 2007, 67, 1446-1454. [CrossRef] [PubMed]

98. Peeker, R.; Abramsson, L.; Marklund, S.L. Superoxide dismutase isoenzymes in human seminal plasma and spermatozoa. Mol. Hum. Reprod. 1997, 3, 1061-1066. [CrossRef] [PubMed]

99. Park, K.; Jeon, S.; Song, Y.-J.; Yi, L.S.H. Proteomic analysis of boar spermatozoa and quantity changes of superoxide dismutase 1, glutathione peroxidase, and peroxiredoxin 5 during epididymal maturation. Anim. Reprod. Sci. 2012, 135, 53-61. [CrossRef] [PubMed]

100. Sikka, S.C. Relative impact of oxidative stress on male reproductive function. Curr. Med. Chem. 2001, 8, 851-862. [CrossRef] [PubMed]

101. Dhanda, O.P.; Rao, B.R.; Razdan, M.N. Sorbitol dehydrogenase \& hyaluronidase activity in buffalo semen. Indian J. Exp. Biol. 1981, 19, 286. [PubMed]

102. Gavella, M.; Cvitkovic, P. Semen LDH-X deficiency and male infertility. Arch. Androl. 1985, 15, $173-176$. [CrossRef] [PubMed]

103. Virji, N. LDH-C4 in human seminal plasma and its relationship to testicular function. I. Methodological aspects. Int. J. Androl. 1985, 8, 193-200. [CrossRef] [PubMed]

104. Wheat, T.E.; Goldberg, E. Sperm-specific lactate dehydrogenase C4: Antigenic structure and immunosuppression of fertility. In Isozymes. Current Topics in Biological and Medical Research; Scandalios, J.G., Whitt, G.S., Eds.; Liss: New York, NY, USA, 1983; pp. 113-130.

105. Duan, C.; Goldberg, E. Inhibition of lactate dehydrogenase C4 (LDH-C4) blocks capacitation of mouse sperm in vitro. Cytogenet. Genome Res. 2003, 103, 352-359. [CrossRef] [PubMed]

106. Zimmerman, S.W.; Yi, Y.J.; Sutovsky, M.; van Leeuwen, F.W.; Conant, G.; Sutovsky, P. Identification and characterization of RING-finger ubiquitin ligase UBR7 in mammalian spermatozoa. Cell. Tissue Res. 2014, 356, 261-278. [CrossRef] [PubMed]

107. Zimmerman, S.W.; Manandhar, G.; Yi, Y.J.; Gupta, S.K.; Sutovsky, M.; Odhiambo, J.F.; Powell, M.D.; Miller, D.J.; Sutovsky, P. Sperm proteasomes degrade sperm receptor on the egg zona pellucida during mammalian fertilization. PLoS ONE 2011, 6, e17256. [CrossRef] [PubMed]

108. Jaiswal, A.; Joshi, P.; Kumar, M.V.; Panda, J.N.; Singh, L.N. Angiotensin converting enzyme in the testis and epididymis of mammals. Andrologia 1984, 16, 410-416. [CrossRef] [PubMed]

109. Yotsumoto, H.; Sato, S.; Shibuya, M. Localization of angiotensin converting enzyme (dipeptidyl carboxypeptidase) in swine sperm by immunofluorescence. Life Sci. 1984, 35, 1257-1261. [CrossRef]

110. Krassnigg, F.; Niederhauser, H.; Placzek, R.; Frick, J.; Schill, W.B. Investigations on the functional role of angiotensin converting enzyme (ACE) in human seminal plasma. Adv. Exp. Med. Biol. 1986, 198 Pt A, 477-485.

111. Brentjens, J.R.; Matsuo, S.; Andres, G.A.; Caldwell, P.R.; Zamboni, L. Gametes contain angiotensin converting enzyme (kininase II). Experientia 1986, 42, 399-402. [CrossRef] [PubMed]

112. Vivet, F.; Callard, P.; Gamoudi, A. Immunolocalization of angiotensin 1 converting enzyme in the human male genital tract by the avidin-biotin-complex method. Histochemistry 1987, 86, 499-502. [CrossRef] [PubMed]

113. Dobrinski, I.; Ignotz, G.G.; Fagnan, M.S.; Yudin, S.I.; Ball, B.A. Isolation and characterization of a protein with homology to angiotensin converting enzyme from the periacrosomal plasma membrane of equine spermatozoa. Mol. Reprod. Dev. 1997, 48, 251-260. [CrossRef]

114. Gatti, J.L.; Druart, X.; Guerin, Y.; Dacheux, F.; Dacheux, J.L. A 105- to 94-kilodalton protein in the epididymal fluids of domestic mammals is angiotensin I-converting enzyme (ACE); evidence that sperm are the source of this ACE. Biol. Reprod. 1999, 60, 937-945. [CrossRef] [PubMed]

115. Reeves, P.G.; O'Dell, B.L. Zinc deficiency in rats and angiotensin-converting enzyme activity: Comparative effects on lung and testis. J. Nutr. 1988, 118, 622-626. [CrossRef] [PubMed]

116. Singh, U.S.; Kumar, M.V.; Panda, J.N. Angiotensin converting enzyme in semen and its possible role in capacitation. Andrologia 1985, 17, 472-475. [CrossRef] [PubMed]

117. Kondoh, G.; Tojo, H.; Nakatani, Y.; Komazawa, N.; Murata, C.; Yamagata, K.; Maeda, Y.; Kinoshita, T.; Okabe, M.; Taguchi, R.; et al. Angiotensin-converting enzyme is a GPI-anchored protein releasing factor crucial for fertilization. Nat. Med. 2005, 11, 160-166. [CrossRef] [PubMed]

118. Zigo, M.; Jonakova, V.; Sulc, M.; Manaskova-Postlerova, P. Characterization of sperm surface protein patterns of ejaculated and capacitated boar sperm, with the detection of ZP binding candidates. Int. J. Biol. Macromol. 2013, 61, 322-328. [CrossRef] [PubMed] 
119. Einarsson, S.; Gustafsson, B.; Settergren, I. Alkaline phosphatase activity of epididymal contents in boars with normal or reduced spermatogenesis. Andrologia 1976, 8, 25-28. [CrossRef] [PubMed]

120. Bell, D.J.; Lake, P.E. A comparison of phosphomonesterase activities in the seminal plasmas of the domestic cock, turkey tom, boar, bull, buck rabbit and of man. J. Reprod. Fertil. 1962, 3, 363-368. [CrossRef] [PubMed]

121. Soucek, D.A.; Vary, J.C. Some properties of acid and alkaline phosphates from boar sperm plasma membranes. Biol. Reprod. 1984, 31, 687-693. [CrossRef] [PubMed]

122. Bucci, D.; Isani, G.; Giaretta, E.; Spinaci, M.; Tamanini, C.; Ferlizza, E.; Galeati, G. Alkaline phosphatase in boar sperm function. Andrology 2014, 2, 100-106. [CrossRef] [PubMed]

123. Gillis, B.A.; Tamblyn, T.M. Association of bovine sperm aldolase with sperm subcellular components. Biol. Reprod. 1984, 31, 25-35. [CrossRef] [PubMed]

124. Mildvan, A.S.; Kobes, R.D.; Rutter, W.J. Magnetic resonance studies of the role of the divalent cation in the mechanism of yeast aldolase. Biochemistry 1971, 10, 1191-1204. [CrossRef] [PubMed]

125. Dafeldecker, W.P.; Vallee, B.L. Organ-specific human alcohol dehydrogenase: Isolation and characterization of isozymes from testis. Biochem. Biophys. Res. Commun. 1986, 134, 1056-1063. [CrossRef]

126. Khokha, A.M.; Voronov, P.P.; Zimatkin, S.M. Immunoenzyme and immunohistochemical analysis of class III alcohol dehydrogenase from human testis. Biokhimiia 1994, 59, 997-1002. [PubMed]

127. Cho, C. Testicular and epididymal ADAMs: Expression and function during fertilization. Nat. Rev. Urol. 2012, 9, 550-560. [CrossRef] [PubMed]

128. Chunghee, C. Mammalian ADAMs with Testis-Specific or -Predominant Expression. In The ADAM Family of Proteases; Hooper, N., Lendeckel, U., Eds.; Springer: Dordrecht, The Netherlands, 2005; pp. 239-259.

129. Loeb, J. On Some Non-Specific Factors for the Entrance of the Spermatozoon into the Egg. Science 1914, 40, 316-318. [CrossRef] [PubMed]

130. Rogers, J.; Yanagimachi, R. Release of hyaluronidase from guinea-pig spermatozoa through an acrosome reaction initiated by calcium. J. Reprod. Fertil. 1975, 44, 135-138. [CrossRef] [PubMed]

131. Yanagimachi, R.; Kanoh, Y. Manner of Sperm Entry in Herring Egg, with Special Reference to the Role of Calcium Ions in Fertilization. J. Fac. Sci. Hokkaido Univ. 1953, 11, 487.

132. Yanagimachi, R.; Usui, N. Calcium dependence of the acrosome reaction and activation of guinea pig spermatozoa. Exp. Cell Res. 1974, 89, 161-174. [CrossRef]

133. Gervasi, M.G.; Visconti, P.E. Chang's meaning of capacitation: A molecular perspective. Mol. Reprod. Dev. 2016, 83, 860-874. [CrossRef] [PubMed]

134. Chang, M.C. Fertilizing capacity of spermatozoa deposited into the fallopian tubes. Nature 1951, 168, $697-698$. [CrossRef] [PubMed]

135. Kerns, K.; Zigo, M.; Drobnis, E.Z.; Sutovsky, M.; Sutovsky, P. Zinc ion flux during mammalian sperm capacitation. Nat. Commun. 2018, 9, 2061. [CrossRef] [PubMed]

136. De Jonge, C. Biological basis for human capacitation-revisited. Hum. Reprod. Update 2017, 23, $289-299$. [CrossRef] [PubMed]

137. Florman, H.M.; Jungnickel, M.K.; Sutton, K.A. Shedding light on sperm pHertility. Cell 2010, 140, $310-312$. [CrossRef] [PubMed]

138. Zeng, Y.; Oberdorf, J.A.; Florman, H.M. pH regulation in mouse sperm: Identification of $\mathrm{Na}(+)-, \mathrm{Cl}(-)-$, and $\mathrm{HCO} 3(-)$-dependent and arylaminobenzoate-dependent regulatory mechanisms and characterization of their roles in sperm capacitation. Dev. Biol. 1996, 173, 510-520. [CrossRef] [PubMed]

139. Wang, D.; Hu, J.; Bobulescu, I.A.; Quill, T.A.; McLeroy, P.; Moe, O.W.; Garbers, D.L. A sperm-specific Na+/H+ exchanger (sNHE) is critical for expression and in vivo bicarbonate regulation of the soluble adenylyl cyclase (sAC). Proc. Natl. Acad. Sci. USA 2007, 104, 9325-9330. [CrossRef] [PubMed]

140. Lishko, P.V.; Botchkina, I.L.; Fedorenko, A.; Kirichok, Y. Acid extrusion from human spermatozoa is mediated by flagellar voltage-gated proton channel. Cell 2010, 140, 327-337. [CrossRef] [PubMed]

141. Henkel, R.; Bittner, J.; Weber, R.; Hüther, F.; Miska, W. Relevance of zinc in human sperm flagella and its relation to motility. Fertil. Steril. 1999, 71, 1138-1143. [CrossRef]

142. Wroblewski, N.; Schill, W.-B.; Henkel, R. Metal chelators change the human sperm motility pattern. Fertil. Steril. 2003, 79, 1584-1589. [CrossRef]

143. Miller, M.R.; Kenny, S.J.; Mannowetz, N.; Mansell, S.A.; Wojcik, M.; Mendoza, S.; Zucker, R.S.; Xu, K.; Lishko, P.V. Asymmetrically Positioned Flagellar Control Units Regulate Human Sperm Rotation. Cell Rep. 2018, 24, 2606-2613. [CrossRef] [PubMed] 
144. Kerns, K.; Morales, P.; Sutovsky, P. Regulation of Sperm Capacitation by the 26S Proteasome: An Emerging New Paradigm in Spermatology. Biol. Reprod. 2016, 94, 117. [CrossRef] [PubMed]

145. Yokota, N.; Sawada, H. Sperm proteasomes are responsible for the acrosome reaction and sperm penetration of the vitelline envelope during fertilization of the sea urchin Pseudocentrotus depressus. Dev. Biol. 2007, 308, 222-231. [CrossRef] [PubMed]

146. Sánchez, R.; Deppe, M.; Schulz, M.; Bravo, P.; Villegas, J.; Morales, P.; Risopatrón, J. Participation of the sperm proteasome during in vitro fertilisation and the acrosome reaction in cattle. Andrologia 2011, 43, 114-120. [CrossRef] [PubMed]

147. Chakravarty, S.; Bansal, P.; Sutovsky, P.; Gupta, S.K. Role of proteasomal activity in the induction of acrosomal exocytosis in human spermatozoa. Reprod. Biomed. Online 2008, 16, 391-400. [CrossRef]

148. Ambroggio, X.I.; Rees, D.C.; Deshaies, R.J. JAMM: A Metalloprotease-Like Zinc Site in the Proteasome and Signalosome. PLOS Biol. 2003, 2, e2. [CrossRef] [PubMed]

149. Kim, I.; Kim, C.H.; Kim, J.H.; Lee, J.; Choi, J.J.; Chen, Z.A.; Lee, M.G.; Chung, K.C.; Hsu, C.Y.; Ahn, Y.S. Pyrrolidine dithiocarbamate and zinc inhibit proteasome-dependent proteolysis. Exp. Cell Res. 2004, 298, 229-238. [CrossRef] [PubMed]

150. Clapper, D.L.; Davis, J.A.; Lamothe, P.J.; Patton, C.; Epel, D. Involvement of zinc in the regulation of pHi, motility, and acrosome reactions in sea urchin sperm. J. Cell Biol. 1985, 100, 1817-1824. [CrossRef] [PubMed]

151. Michailov, Y.; Ickowicz, D.; Breitbart, H. $\mathrm{Zn}^{2+}$-stimulation of sperm capacitation and of the acrosome reaction is mediated by EGFR activation. Dev. Biol. 2014, 396, 246-255. [CrossRef] [PubMed]

152. Guidobaldi, H.A.; Cubilla, M.; Moreno, A.; Molino, M.V.; Bahamondes, L.; Giojalas, L.C. Sperm chemorepulsion, a supplementary mechanism to regulate fertilization. Hum. Reprod. 2017, 32, 1560-1573. [CrossRef] [PubMed]

153. Stephenson, J.L.; Brackett, B.G. Influences of zinc on fertilisation and development of bovine oocytes in vitro. Zygote 1999, 7, 195-201. [CrossRef] [PubMed]

154. Backstrom, J.R.; Miller, C.A.; Tokes, Z.A. Characterization of neutral proteinases from Alzheimer-affected and control brain specimens: Identification of calcium-dependent metalloproteinases from the hippocampus. J. Neurochem. 1992, 58, 983-992. [CrossRef] [PubMed]

155. Beek, J.; Nauwynck, H.; Maes, D.; Van Soom, A. Inhibitors of zinc-dependent metalloproteases hinder sperm passage through the cumulus oophorus during porcine fertilization in vitro. Reproduction 2012, 144, 687-697. [CrossRef] [PubMed]

156. Andreychenko, S.V.; Klepko, A.V.; Gorban, L.V.; Motryna, O.A.; Grubska, L.V.; Trofimenko, O.V. Post-Chornobyl remote radiation effects on human sperm and seminal plasma characteristics. Exp. Oncol. 2016, 38, 245-251. [PubMed]

157. Colagar, A.H.; Marzony, E.T.; Chaichi, M.J. Zinc levels in seminal plasma are associated with sperm quality in fertile and infertile men. Nutr. Res. 2009, 29, 82-88. [CrossRef] [PubMed]

158. Dissanayake, D.; Wijesinghe, P.S.; Ratnasooriya, W.D.; Wimalasena, S. Effects of zinc supplementation on sexual behavior of male rats. J. Hum. Reprod. Sci. 2009, 2, 57-61. [CrossRef] [PubMed]

159. Mahajan, S.K.; Prasad, A.S.; McDonald, F.D. Sexual dysfunction in uremic male: Improvement following oral zinc supplementation. Contrib. Nephrol. 1984, 38, 103-111. [PubMed]

160. Prasad, A.S.; Mantzoros, C.S.; Beck, F.W.; Hess, J.W.; Brewer, G.J. Zinc status and serum testosterone levels of healthy adults. Nutrition 1996, 12, 344-348. [CrossRef]

161. Kilic, M. Effect of fatiguing bicycle exercise on thyroid hormone and testosterone levels in sedentary males supplemented with oral zinc. Neuro Endocrinol. Lett. 2007, 28, 681-685. [PubMed]

162. Underwood, E.; Somers, M. Studies of zinc nutrition in sheep. I. The relation of zinc to growth, testicular development, and spermatogenesis in young rams. Aust. J. Agric. Res. 1969, 20, 889-897. [CrossRef]

163. Irani, M.; Amirian, M.; Sadeghi, R.; Lez, J.L.; Latifnejad Roudsari, R. The Effect of Folate and Folate Plus Zinc Supplementation on Endocrine Parameters and Sperm Characteristics in Sub-Fertile Men: A Systematic Review and Meta-Analysis. Urol. J. 2017, 14, 4069-4078. [PubMed]

164. Hadwan, M.H.; Almashhedy, L.A.; Alsalman, A.R. Oral Zinc Supplementation Restores Superoxide Radical Scavengers to Normal Levels in Spermatozoa of Iraqi Asthenospermic Patients. Int. J. Vitam. Nutr. Res. 2015, 85, 165-173. [CrossRef] [PubMed] 
165. Arangasamy, A.; Venkata Krishnaiah, M.; Manohar, N.; Selvaraju, S.; Guvvala, P.R.; Soren, N.M.; Reddy, I.J.; Roy, K.S.; Ravindra, J.P. Advancement of puberty and enhancement of seminal characteristics by supplementation of trace minerals to bucks. Theriogenology 2018, 110, 182-191. [CrossRef] [PubMed]

166. Leitzmann, M.F.; Stampfer, M.J.; Wu, K.; Colditz, G.A.; Willett, W.C.; Giovannucci, E.L. Zinc Supplement Use and Risk of Prostate Cancer. J. Natl. Cancer Inst. 2003, 95, 1004-1007. [CrossRef] [PubMed]

167. Plum, L.M.; Rink, L.; Haase, H. The essential toxin: Impact of zinc on human health. Int. J. Environ. Res. Public Health 2010, 7, 1342-1365. [CrossRef] [PubMed]

168. O'Flaherty, C.; Fournier, D.M. Reactive oxygen species and protein modifications in spermatozoa. Biol. Reprod. 2017, 97, 577-585. [CrossRef] [PubMed]

169. Powell, S.R. The antioxidant properties of zinc. J. Nutr. 2000, 130, 1447S-1454S. [CrossRef] [PubMed]

170. Talevi, R.; Barbato, V.; Fiorentino, I.; Braun, S.; Longobardi, S.; Gualtieri, R. Protective effects of in vitro treatment with zinc, d-aspartate and coenzyme q10 on human sperm motility, lipid peroxidation and DNA fragmentation. Reprod. Biol. Endocrinol. 2013, 11, 1-10. [CrossRef] [PubMed]

171. Gualtieri, R.; Barbato, V.; Fiorentino, I.; Braun, S.; Rizos, D.; Longobardi, S.; Talevi, R. Treatment with zinc, d-aspartate, and coenzyme Q10 protects bull sperm against damage and improves their ability to support embryo development. Theriogenology 2014, 82, 592-598. [CrossRef] [PubMed]

172. Posthuma, L.; Baerselman, R.; Van Veen, R.P.M.; Dirven-Van Breemen, E.M. Single and Joint Toxic Effects of Copper and Zinc on Reproduction ofEnchytraeus crypticusin Relation to Sorption of Metals in Soils. Ecotoxicol. Environ. Saf. 1997, 38, 108-121. [CrossRef] [PubMed]

173. Barceloux, D.G.; Barceloux, D. Zinc. J. Toxicol. Clin. Toxicol. 1999, 37, 279-292. [CrossRef] [PubMed]

174. Johnson, F.O.; Gilbreath, E.T.; Ogden, L.; Graham, T.C.; Gorham, S. Reproductive and developmental toxicities of zinc supplemented rats. Reprod. Toxicol. 2011, 31, 134-143. [CrossRef] [PubMed]

175. Manzo, S.; Schiavo, S.; Oliviero, M.; Toscano, A.; Ciaravolo, M.; Cirino, P. Immune and reproductive system impairment in adult sea urchin exposed to nanosized $\mathrm{ZnO}$ via food. Sci. Total Environ. 2017, 599-600, 9-13. [CrossRef] [PubMed]

176. Merrells, K.J.; Blewett, H.; Jamieson, J.A.; Taylor, C.G.; Suh, M. Relationship between abnormal sperm morphology induced by dietary zinc deficiency and lipid composition in testes of growing rats. Br. J. Nutr. 2009, 102, 226-232. [CrossRef] [PubMed]

177. Ding, B.; Zhong, Q. Zinc deficiency: An unexpected trigger for autophagy. J. Biol. Chem. 2017, 292, 8531-8532. [CrossRef] [PubMed]

178. Jaiswal, B.S.; Eisenbach, M. Capacitation. In Fertilization; Hardy, D.M., Ed.; Academic Press: Cambridge, MA, USA, 2002; pp. 57-117.

179. Aitken, R.J.; Baker, M.A.; Nixon, B. Are sperm capacitation and apoptosis the opposite ends of a continuum driven by oxidative stress? Asian J. Androl. 2015, 17, 633-639. [CrossRef] [PubMed]

180. Yi, Y.J.; Manandhar, G.; Oko, R.J.; Breed, W.G.; Sutovsky, P. Mechanism of sperm-zona pellucida penetration during mammalian fertilization: $26 \mathrm{~S}$ proteasome as a candidate egg coat lysin. Soc. Reprod. Fertil. Suppl. 2007, 63, 385-408. [PubMed]

(C) 2018 by the authors. Licensee MDPI, Basel, Switzerland. This article is an open access article distributed under the terms and conditions of the Creative Commons Attribution (CC BY) license (http://creativecommons.org/licenses/by/4.0/). 